This is a self-archived version of an original article. This version may differ from the original in pagination and typographic details.

Author(s): Kall, Kairit; Lillie, Nathan; Sippola, Markku; Mankki, Laura

Title: Overcoming Barriers to Transnational Organizing Through Identity Work : FinnishEstonian Trade Union Cooperation

Year: 2019

Version: Accepted version (Final draft)

Copyright: (c) The Author(s) 2018.

Rights: In Copyright

Rights url: http://rightsstatements.org/page/InC/1.0/?language=en

Please cite the original version:

Kall, K., Lillie, N., Sippola, M., \& Mankki, L. (2019). Overcoming Barriers to Transnational Organizing Through Identity Work : Finnish-Estonian Trade Union Cooperation. Work, Employment and Society, 33(2), 208-225. https://doi.org/10.1177/0950017017746086 


\title{
Overcoming Barriers to Transnational Organizing Through Identity Work: Finnish-Estonian Trade Union Cooperation
}

\begin{abstract}
This article analyses a project by Finnish and Estonian unions to adopt 'organizing model' strategies through establishing the transnational 'Baltic Organising Academy'. Initially aimed at Estonian workplaces, successful campaigns inspired Finnish unions to copy the model in Finland. This transnational cooperation was originally motivated by labour market interdependence between the two countries, and the failure of past social-partnership oriented union strategies in Estonia. The willingness of Finnish and Estonian unions to commit financial and organizational resources to transnational cooperation around an 'organizing model' marks a dramatic departure from the unions' previous strategies. This change of strategy was accomplished by a cadre of transnational activists who developed and raised support for organizing in the face of structural challenges and ideological opposition by some union officials to the confrontational style of the 'organizing model'. The project's transnational organizing exemplifies one possible solution to union weakness in Eastern Europe, and underlines the importance of 'identity work' in building transnational trade union coalitions around organizing.
\end{abstract}

\section{Keywords}

Estonia, Finland, transnational union cooperation, organizing model

\section{Introduction}

In 2010, a coalition of unions from countries in the Baltic region formed the 'Baltic Organising Academy' (BOA), in an attempt to halt union decline by introducing 'organizing model' strategies in Estonia, Latvia and Lithuania. While the project has so far had only very limited impact in the other 
Baltic and Nordic countries, the project inspired Finnish and Estonian unions to develop strong bilateral transnational organizing cooperation. For Finnish and Estonian unions implementing the BOA has involved not only reimagining union geographies, but reorienting union identities, away from social partnership and towards more confrontational forms of unionism. The Finnish-Estonian BOA cooperation is a rare example of sustained, successful transnationalism backed by high-level strategies, and fully implemented in action on the ground.

We argue that behind this success is a long process of identity work by Finnish and Estonian unionists, which pre-dates and extends well beyond organizing. Finnish and Estonian unions overcame a 'double barrier' in developing cooperation around bi-national organizing. First, they had to overcome the national focus and insularity inherent to union activity. Second, they had to 'sell' their organizing project to union leaderships focused on social partnership and membership servicing. These adjustments involved a process of 'identity work,' to build among Finnish and Estonian trade unionists an organizing mindset, and a cadre of unionists skilled in and committed to organizing. Although trade union survival and improved bargaining leverage provide the BOA's rationale, the key factor behind its success is 'identity work', through which trust has been established and common norms, objectives and identities have been (re)constructed. A cadre of transnational union activists skilfully framed organizing as a viable approach in Estonia and Finland. Following Greer and Hauptmeier (2012), we argue that identity work is essential for initiating and sustaining transnational trade union cooperation.

Estonia and Finland are linguistically and culturally similar neighbours, whose labour and product markets are linked by European Union (EU) free movement. Finland, however, has a comparatively high union density of 69\%, while Estonia's is 6\% (Visser, 2015). Since independence in 1991, Estonia has become a magnet for Finnish capital, a source country for low wage migration into Finland, and a 
laboratory for Finnish multinational companies to try out non-union working practices. Finnish unions have aided Estonian unions since the early 1990s, trying to build in Estonia the industry-level bargaining and social dialogue typical in Finland. Since Estonian unions are weak, management has usually seen little reason to engage with them (Author A). While cooperation around social partnership in Estonia failed, this history of cooperation provided a shared background on which likeminded factions in both countries built in promoting the 'organizing model'. The original idea was to implement the organizing model only in Estonia but Estonian successes inspired Finnish unionists to imitate these practices in the very different Finnish environment in Finland.

We begin by describing the 'organizing,' 'transnationalism' and 'social partnership' frames, and their compatibilities and tensions. We then turn to explaining how identity work can reconcile the tensions in service of transnational organizing strategies. After presenting our case study methodology, we describe the pre-BOA Nordic-Baltic union cooperation, the BOA's genesis, the success and spread of the organizing model in Estonian, and its imitation by Finnish unions. We highlight the role of various aspects of identity work in building and sustaining the transnational organizing model. The final section concludes with a discussion of the factors supporting the BOA's success, and assessing its long-term prospects and relevance to other contexts.

\section{The Organizing Model}

We understand the 'organizing model' in terms of both internal and external organizing (Connolly, Marino \& Martinez Lucio, 2017; Heery et al., 2000). Internal organizing refers to mobilizing and stimulating activism among already existing union members. External organizing describes practices

that contribute to membership growth, such as recruiting in workplaces where there is as yet no union presence (Heery et al., 2000: 996). Although the main focus of BOA has been external organizing 
(especially in low-density Estonia), internal organizing has also been relevant (Häkkinen, 2013: 11$13)$.

The 'organizing model' developed in the 1980s and 90s as a union response to the virulently antiunion environment of the United States (US). Advocates of the model promoted mobilization of current and potential union members and a set of aggressive union organizing tactics, which when taken together improved union 'win-rates' in the National Labor Relations Board representation elections which are typically the focus of US organizing campaigns (cf. Bronfenbrenner, 1997). The model assumes a hostile management which unions counter by mobilizing rank and file workers. Unions organize in secret for as long as possible, preparing workers mentally for a management onslaught, researching the weaknesses and vulnerabilities of targeted firms and building rank and file organization. This process encourages workers to 'reimagine' their interests as collective and classbased, in opposition to management (Simms, 2012). In short, the frame takes conflict as given, and emphasizes tactics which have been proven effective (Bronfenbrenner, 1997), though under an admittedly narrow set of assumptions (de Turberville, 2004).

The organizing model has been criticized on many fronts. Union officials focused on partnership and membership servicing sometimes oppose the organizing model because they believe it competes with their own goals and priorities (Fiorito, 2004). Although emphasizing grassroots mobilization, it is staff-driven, following a strict playbook, and implemented by professional organizers (Fletcher and Hurd, 2001). Unlike partnership, which focuses on process legitimacy and compromise, the organizing model emphasizes specific goals, and mobilizes resources such as staff, political influence and worker support, to achieve those goals. Thus, it requires unions to allocate resources which might have been used elsewhere. This is arguably facilitated by a strong central leadership (Krzywdzinski, 2010), which is however in service of a rank-and-file based mobilizing strategy (Milkman, 2006). The 
apparent uniformity of the organizing model as a one-size-fits-all approach belies the complex environments and organizing challenges unions face in difference contexts (de Turberville, 2004). Some question its potential to succeed as a macro revitalization strategy for the labour movement as a whole because the obsessive focus with organizing practice neglects broader issues of rebuilding class power (Simms, 2012; Simms and Holgate, 2010). Related to this, organizing is often seen only as a way to bring in new members and increase union density, leaving aside the issue of empowering and mobilizing existing union members (Connolly et al., 2017: 321-322).

In practice unions adjust the model to their circumstances. Lessons from the 'organizing model' have proven attractive to unions in many countries, including highly regulated industrial relations systems such as the Netherlands, Germany, and Denmark. Inevitably, this has involved adaptation to local conditions. The end goals of organizing campaigns differ from one country to another, since these usually involve building workplace institutions, and the forms these take depend on national labour law. For example, in Germany, organizing emphasizes establishing works councils instead of signing collective agreements (Turner, 2009). For Dutch unions, internal organizing, or mobilizing and activating the membership, is usually more important than winning collective agreements per se, since the legal extension of collective agreements means that workers are typically already covered. However, the enforcement of these agreements requires shop-floor union leverage which can be achieved through internal organizing, which strengthens the unions' legitimacy by promoting reforms and democratisation within unions. This does not exclude external organizing, which the Dutch unions also do, to extend union representation and regulation to previously unorganized groups of workers (Connolly et al. 2017). Arnholz et al. (2016) note that organizing advocates in Denmark 'translate' the organizing model in ways which legitimate it in the Danish context, selecting only the parts which they regard as well suited to Denmark's high union-density, highly institutionalized context. 
Central and Eastern Europe (CEE) unions face weak institutional contexts and low union density. In some ways this environment is similar to the US, and could theoretically be fertile ground for external organizing. An important limitation has been, however, that CEE unions lack the resources for organizing. Furthermore, they are often caught in a tradition of servicing unionism inherited from state socialist times. Polish unions, and in particular Solidarność, enthusiastically adopted the organizing model beginning in the late 1990s, inspired by international cooperation and the entrance of a new generation of unionist into union leadership. Polish organizing, however, has had to fight for its budget share and remains relatively small scale (Krzywdzinski, 2010).

\section{The Transnationalism Frame}

Compared to the organizing model, union transnationalism represents a broader field of activities, with more varied ideological underpinnings. While much of it can be understood as conventional trade union interest micropolitics within firms (Greer and Haupmeier, 2012), or the geographical expansion of union activities to regain bargaining leverage lost to globalization (Author B), at the EU level unions push pro-integrationist and social dialogue agendas, shaped by the EU's political opportunity structure (Gumbrell-McCormick and Hyman, 2013). There is also an international campaigning undercurrent (Author B) and many examples of cooperation motivated by radical leftist internationalism (Durrenberger, 2009).

It is unusual for unions to directly organize members across national boundaries. International organizing assistance usually occurs in partnership with local unions supported by foreign unions' finances, training and sometimes solidarity. A recent failed effort proving the rule is the German construction union IG BAU's effort to establish a European Migrant Workers Union (EMWU). The EMWU accepted members from any industry or country, and tried to establish effective representation for Polish migrant workers in Germany. It encountered resistance from other German 
unions jealous of their jurisdiction. It also had difficulty recruiting migrant members. Its resources were eventually absorbed back into IG BAU (Author B). On the other hand, the London-based International Transport Workers' Federation (ITF) Seafarers' Section has maintained for decades a successful global bargaining system allowing for direct seafarer membership, although these bargaining rights are normally transferred to member unions. The ITF's situation is unusual in that 'organizing' is mostly through secondary action, so convincing the seafarers to join is useful but not essential (Author B), obviating the problem of recruiting workers into a 'foreign' union.

\section{The Social Partnership Frame}

'Social partnership' in some contexts is defined as mutual gains bargaining (Kelly, 2004), but its Nordic implementation is heavily imbued with a social regulatory role for unions. In Finland, it is more common to use the term 'labour market parties', recognizing the role of regulated conflict in Nordic labour policy (Kettunen, 2012). Since industrialization in the 1970s and 80s, strong national social partner relations in Finland have been backed by a societal consensus supportive of the role of unions, and nearly universal union membership. Unions assure membership through shop steward networks and a Ghent-system linkage of membership to unemployment benefits (Böckerman and Uusitalo, 2006). External organizing has not been important, because there has not been anyone to organize. Unions regard themselves as partners in national politics, with a role in shaping Finland's political-economy and safeguarding its competitiveness. This role is sometimes at tension with collective action or 'movement' (Kettunen, 2004: 305), such as organizing often entails.

In Estonia social partnership is weak - although unions strive for it - and at the national level often takes an 'illusory' form (Woolfson and Kallaste, 2011). With low membership levels and withdrawal of state support, Estonian unions have lost the financial stability and policy influence which was the legacy of their state-socialist heritage and subsequent EU promotion of their social partner role (ibid.). 
Due to employers' disinterest, sectoral bargaining is rare and most collective agreements are company level. Unions mainly operate through peaceful collective bargaining and routine servicing of existing members. The lack of a union protest culture hampers the use of more aggressive tactics (Author A).

Finnish and Estonian unionists value their membership servicing and social partnership regulatory roles, which involve a mind-set in conflict with that of the organizing model. However, like de Turberville (2007) we do not see servicing as incompatible with organizing. We also recognize that social partnership relies on union power resources (Turner, 1998), which in some cases depend on organizing. In the absence of union power resources, partnership either collapses, or becomes a legitimation tool for management or the state (Woolfson and Kallaste, 2011). We argue that the organizational infrastructure of social partnership and servicing, in the absence of continuing struggle to establish unions' position in society, can over time result in unions no longer having the ability to mobilize workers. In such cases, implementing 'organizing unionism' requires changes in union structures, personnel and identity (Voss and Shermann, 2000; Krzywdzinski, 2010). The introduction of organizing is sometimes opposed by unionists who believe it wastes resources which could be used for servicing, or disrupts existing trust relations with management. These tensions between organizing, partnership and servicing are inevitable, and managing them is an integral part of adopting the organizing model.

\section{Identity Work}

Transnational union organizing cooperation requires organizational innovation both in terms of transnational linkages as well as the development of an organizing model. Both dimensions require 'identity work', to bring about the oppositional and campaigning orientation needed to organize and deepen the mutual trust needed for successful transnational cooperation. 'Identity work' refers to 'anything people do, individually or collectively, to give meaning to themselves or others' (Schwalbe 
and Mason-Schrock, 1996: 115). During the process collective (or individual) identities are created, sustained and modified (Snow and Anderson, 1987; Snow and McAdam, 2000). Identity construction, as a form of identity work is, according to Snow and McAdam (2000: 53), facilitated by framing, collective action, or a combination of the two. As concluded by Benford and Snow (2000: 612), 'framing processes have come to be regarded, alongside resource mobilization and political opportunity processes, as a central dynamic in understanding the character and course of social movements.' Framing is a processual phenomenon introducing mobilizing ideas and meanings, with an important role for agency and the generation of interpretative frames for identity (and reality) construction (Benford and Snow, 2000: 614).

The identity work concept has been applied to union transnationalism by Greer and Hauptmeier (2012), who emphasize its role in sustaining cooperation between unions in different production sites at General Motors (GM) Europe. Greer and Hauptmeier point out that transnational coalitions between unions lack institutional support; following Cooke (2005), they note that because of this, local unions face a prisoners' dilemma when acting collectively. In order not to be undermined by management whipsawing, GM unions needed to change the rules of the game. Through identity work over time GM unions constructed a common interest and purpose, countering management efforts to confound their cooperation. This was accomplished through a framing and trust building process involving face-to-face interactions, formal and informal socializing, and education and mobilization of workers (Greer and Hauptmeier, 2012). Identity work allowed the unionists to overcome the limitations of existing institutional infrastructure and embedded identities, permitting adaptation to changing productive structures and management strategies.

\section{The Double Barrier}


Transnational organizing involves overcoming a double barrier, to change into organizing unions and to organize workers in another country. In the current case, identity work enabled the unions not only to build cooperation by reframing their interests, but also shifted those unions' identities to prioritize organizing, which formerly had been considered in conflict with their principles. Both Finnish and Estonian unions hold to their own versions of 'social partnership', and some unionists regard the organizing model as threatening to this.

In some respects, the organizing and transnational cooperation frames overlap, in emphasizing trade union solidarity and mutual aide, as well as strategic innovation and adaptation to changing economic environments. Still, 'transnational cooperation' covers a wide variety of activities and perspectives (Author B) while organizing is focused. In the Finland-Estonia case previous cooperation was built on a transnational social partnership paradigm. Overcoming the double barrier required constructing the organizing model frame on top of an earlier process of transnational identity work, out of which a cadre of union officials and activists emerged committed to organizing and rebuilding union strength in a joined labour market.

\section{Methodology}

The literature suggests that there are many barriers to implementing the organizing model in different national contexts and especially transnationally. The main question guiding our research was: How have the Estonian and Finnish unions surmounted these barriers? Answering this question involved analysing the process of identity work and union strategic decision making, through interview testimony, (participant) observations and documentary material over several years. Using these three types of data sources, we triangulated our findings about this case in a way which has possible relevance to organizing efforts in other contexts. 
Our case study draws on 16 in-depth interviews (conducted in 2014-2016) with trade union officials and organizers in Estonia and Finland, participant observation during organizer training and organizing visits to companies (in 2016), 26 interviews conducted with Baltic area trade unionists in 2004-2005, cooperation workshops involving Finnish and Estonian unions (in 2004-2005) and documents such as BOA meeting minutes, progress reports and union newsletters. The 2014-2016 data was collected with the aim of understanding the decision making process and strategy behind the implementation of the organizing model, and the development of Finnish-Estonian union cooperation. The 2004-2005 data was collected during an EU-funded Nordic-Baltic project 'Promoting Information, Consultation and Participation in the Estonian, Latvian and Lithuanian Industry and Construction Sectors' with the goal of tracking industrial relations developments in the Baltic States. The data was thematically coded and analysed to trace the development of trans-Baltic cooperation over more than a decade, to see changes in strategy, structures, and collective action frames. One limitation is that we did not conduct detailed research on actors from other Nordic and Baltic countries, which would have provided more generalizability to our arguments.

\section{Exporting the Finnish Model to Estonia}

Since the early 1990s, Finnish unionists have tried to guide the Estonians towards the Finnish model of coordinated industry level bargaining and social dialogue. Finnish unions tend to regard their system as a superior model for weaker labour movements to follow. This attitude fuelled a 'big brother mentality', assuming Estonians could follow the same path, minimizing cultural differences and local particularities (Skulason and Jääskeläinen, 2000). One official from the Finnish Metalworkers' Union (Metalliliitto) critically explains this attitude:

/.../ Look, [we told them] we are strong, we have high organization rates and the funniest part was that we insisted that they should have a dialogue with the employers, when the employers 
didn't want to have a dialogue with them. But we insisted that you should find a way to have a dialogue with the employers. (Metalliliitto official \#1, January 2015)

Finnish-Estonian union cooperation developed in the context of many EU initiatives, as well as multilateral cooperation between Nordic and Baltic State unions, under the Baltic Sea Trade Union Network (BASTUN), formed in 1999 (Schymik, 2013: 75). Finnish-Estonian cooperation is much deeper than these, having been developed through numerous bilateral initiatives as well. These include, for example, the Finnish unions establishing an information office in Estonia for Estonians considering working in Finland, and the Estonian ETKA and Finnish private service sector union PAM concluding an agreement in the late 2000s making it easier for ETKA members to join PAM when they move to Finland (ETKA official, September 2014). Notably, the Finnish Seamen's Union (SMU) and the Estonian Seamen's Independent Union (EMSA) have a longstanding cooperation in representing seafarers on Baltic ships, which extends into shore-based hotels. Ships on Baltic Sea routes have frequently been crewed by both Estonians and Finns, and their shop-floor representation has been a cooperative endeavour (Conversation with EMSA's president, April 2010).

Prior to the turn to organizing there were scattered efforts to recruit Estonians with help from Finnish unions. For example, the Finnish Chemical Workers' and Estonian Light Industry Trade Union shared the costs of a recruiter (EKTAL official, November 2005). The Finnish Metalliliitto and the Federation of Estonian Metal Workers' Unions (EMAF), cooperated by using the Finnish union's leverage in headquarters to help organize Estonian subsidiaries. This strategy brought some growth in membership, but was later undermined by the dismissal of many Estonian union members (EMAF official, March 2005). Furthermore, the Estonian Trade Union Confederation (EAKL) and the Central Organization of Finnish Trade Unions (SAK) organized joint events in 2005 on recruiting and a seminar on strike strategy (EAKL official \#1, August 2006). These efforts demonstrated the 
recognition of the problem of low organization rates in Estonia, pointing toward a need for more systematic organizing (Häkkinen, 2013).

Although Finnish-Estonian cooperation failed to turn around union decline in Estonia, by 2010, when the organizing model began to be considered, Estonian and Finnish unions had established a cooperation culture and personal contacts through joint activities spanning two decades. Although the interdependence of labour markets was an underlying motivation, the routines of cooperation made joint introduction of the organizing model possible:

The Nordics motivation in the beginning was to protect their labour market, this is clear. From this initial motivation, friendships developed and a kind of routine that they support. (Association of Estonian Energy Workers' Trade Unions' (AEEWTU) official, March 2015)

\section{Constructing an organizing identity: the importance of framing}

The BOA began as a multinational effort involving several Nordic industrial, service and transport union federations. These met in 2010 and decided to invite Baltic unions into organizing cooperation efforts with Nordic union counterparts. Inspiration to follow the organizing model came from the American Change to Win (CtW) initiative. CtW European office staff also provided initial training. In 201132 organizations joined BOA, including 11 Finnish, two Swedish, four Danish, six Estonian and two Lithuanian unions, the Association of Estonian Industrial Trade Unions (EAKL), the Friedrich Ebert Foundation and the Council of Nordic Trade Unions (Häkkinen, 2013: 6).

The poor record of previous Nordic-Baltic union projects meant that Baltic unions needed to be persuaded to become involved in yet another one. Compared to the Finnish-Estonian relationship, 
cooperation between the Scandinavian unions and Latvian and Lithuanian ones was not as substantial. The Swedes proved reluctant to invest too much personnel-time (Metalliliitto official \#1, January 2015) and the Latvian and Lithuanian unions were also hesitant. Two Lithuanian industrial unions showed did show interest, however (Häkkinen, 2013: 6). The Latvians were least willing to take part, one reason being that they were concerned about being controlled by the Nordic unions. A former Estonian BOA coordinator relates that the Latvians unequivocally stated 'give us money and we will see ourselves what we will do, you are not coming to teach us' (BOA coordinator interview, December 2014). In the end, the Finnish and Estonians moved forward with practical cooperation, and initial operations were therefore concentrated in Estonia. The Lithuanians also undertook some less extensive activity, while the other participants decided mostly to wait and observe.

The Academy was based on the principle that all participating organizations should provide resources: either finances, personnel, or both. For Estonian unionists who backed the plan, personal contacts and the history of cooperation overcame their initial scepticism:

In the beginning... I did not totally agree and I was not interested in taking part [in the BOA]. But from the Finnish side... I cannot say that they pressured me, but they said 'How come you are not taking part?' We were old friends, right? (AEEWTU official, March 2015)

In addition to personal relations, Estonian unionists cited low and declining membership, difficulty concluding collective agreements, financial hardship, and trends towards subcontracting threatening their future membership, as motives for joining. Even after it was initiated, its advocates had to 'sell' it to other staff in their unions. Organizing was alien to many Estonian unionists and it needed to be framed in a way which would overcome the resistance of those sceptical about aggressive social 
movement tactics and symbolic protest. One unionist relates how some unionists reacted to these tactics:

I remember in 2000 I suggested that we should start thinking about that kind of thing [organizing].... I was laughed at: 'You are talking madness, what is organizing? What the hell? We already have so many members. Members should come to us, we shouldn't go to the members.' We did those [militant] campaigns in the central federation. I remember there was a campaign by the nurses' union in which we used a stretcher and put ketchup on it and the girls were lying on it. Ligi [an Estonian right wing politician] had to jump up and he was swearing 'nasty, nasty, nasty'. The conservatives on the board of central federation asked: What are you doing!? You are going there with a coffin and you cannot do that! (former Estonian BOA country coordinator, December 2014)

For the Estonians, introducing the BOA meant organizational transformation. Although some unionists were directly involved in the transnational cooperation, to succeed the organizing model had to be domesticization into wider union circles, involving unionists who had not previously been involved. More dramatically, they had to be willing to try different ways of approaching workers and employers. For the Finnish unions, the decision was perhaps easier, since their initial commitment was primarily financial.

Benford and Snow (2000) relate that framing can involve diagnostic, prognostic, and motivational aspects, which Finnish and Estonian organizing model advocates undertook together. The organizing model was first promoted in Estonia as a way to prevent Estonia becoming a union-free zone; Finnish adoption began later. One Estonian and one Finnish trade unionist who had studied the model and initiated the project became its main advocates. They diagnosed low union density and passive social 
partnership/servicing unionism as problems, framing the organizing approach as the only way to ‘save' Estonian unions. They publicized successful examples from other countries. This signalled a move away from the previous 'big brother mentality', as the Finnish model was no longer exemplary.

The next aspect is prognostic framing or 'the articulation of a proposed solution to the problem, or at least plan of attack, and the strategies for carrying out the plan' (Benford and Snow, 2000: 616). The main BOA initiators laid out detailed plans for the 'Organizing Academy' which was introduced during numerous formal and informal meetings with union officials. They prepared training materials, so those who took part had a ready-made package to follow. Finally, motivational framing provided a 'rationale for engaging in ameliorative collective action' (ibid: 617), like emphasising the need to end the downward membership spiral, the interdependency of labour markets, mutual obligations and 'being in the same boat'.

Finnish unions were motivated by the competitive threat of a largely union free zone in the Baltic States. This was related both to capital moving to Estonia, and labour to Finland. For example, a PAM official pointed out that a two-euro-an-hour-salary in Tallinn is typical for a cleaner, while in Finland the minimum salary is 8,87 per hour (as per the collective agreement for commercial cleaning, 20132017). Estonian migrants are a major group in low-paid service jobs in Finland (PAM, 2009). A PAM official relates:

If you think about the whole picture, course it would be to everyone's advantage if there were functional labour movements in nearby countries, because there is freedom of movement of labour [within the EU]...so that the workers learn that they have rights in every country /.../ at the moment, some [migrants] know their rights here [in Finland] but don't know that they have a labour movement in their own country, and 
they might not trust it there. (PAM official, November 2014)

The Finnish Metalliliitto also emphasised the failure of the scattered campaigns and initiatives initiated by the Finnish unions in Estonia in the past, admitting that that despite long-standing cooperation between Metalliliitto and EMAF they had gained few new members: 'We can keep them alive in that sense, the EMAF, but it doesn't lead us anywhere. We should do something differently.' (Metalliliitto official \#1, January 2015). The well-planned BOA initiative rationalized various union efforts and brought them under one strategic vision. A cadre of committed individuals initiated BOA through personal contacts built from past cooperation, and then set about domesticating the strategy through diagnostic, prognostic and motivational framing. This was solidified and sustained through collective action, described in the following section.

\section{Engaging in collective action: BOA's organizing in Estonia}

Campaign work started in Estonia in May 2012. The idea was that the Finnish (and to a lesser extent also Danish and Swedish) unions support the Estonians financially, through strategic information, and sometimes solidarity. The Estonians set up a campaign office, and planned and executed campaigns. Training was supported by all the partners. All participants committed to re-investing at least 35 per cent of campaign-generated membership fees into organizing (Häkkinen, 2013: 7). Finnish unions made bilateral agreements with partner organizations. For example, PAM financed one Estonian organizer's salary, and contributed 10\% of a Finnish official's work time in Finland. They promised also to support ETKA in negotiations by providing strategic information (PAM official, November 2014).

The approach followed the organizing model archetype closely. By the end of 2014 Estonia had seven BOA organizers in services, transportation and manufacturing. Organizers, in collaboration with 
Nordic colleagues, strategically targeted companies with few or no union members, but which they believed to be 'winnable'. Nordic companies were sometimes preferred because of the potential to pressure the Nordic management. They did not usually solicit Nordic union support openly, but the Nordic ownership may account the Estonians' success at obtaining 'organizing neutrality agreements,' in which management agrees not to actively oppose unionization. The reason for Finnish unions' low profile was that in this way the Estonians could achieve and take credit for their own victories. Pressuring and picketing in Finland was available as a back-up strategy (PAM's official, November 2014). Picketing by Estonian workers in Finland played a role in winning neutrality from the hotel company Sokotel in 2015, and then a collective agreement in 2016.

As is typical in the organizing model, the most important element was one-on-one conversations with workers, to determine the most important bargaining issues, to explaining what a union is, and to build workers' confidence in collective solutions. Organizing in a post-soviet context has its challenges: the younger generation generally has no knowledge of trade unions, while older employees still associate unions with their Soviet-era function of distributing goods given by the state. These one-on-one conversations also promote a collectivist worker mentality versus the employer:

[During organizing conversations organizer explains to the workers that] you basically have no other options [than the union] to improve your working life. You cannot stand and wait for the employer to come and pat you on the shoulder, say 'good job, next month I will give you 100 Euros more'. Those kinds of things do not happen. They are making profit, why should they change anything? (BOA organizer \#2, October 2014) 
Worker passivity and fear of employer retaliation make organizing difficult. As is common elsewhere, Estonian employers used ideological manipulation, such as labelling unions as communists and more direct opposition, such as inviting workers to one-on-one talks to pressure them not to join.

A high priority is recruiting 'natural leaders', who help recruit other workers and eventually maintain union structures that can survive and grow after the organizer has left. Legally only five members are required to set up a union. In practice, however, campaigns aim to build high density on-site organizations, with elected shop stewards and board members, committed members, the ability to use industrial action when necessary, and a company-specific collective agreement (Häkkinen, 2013: 11). Organizers start by organizing enough workers to have leverage over the employer, and only then do they contact the employer. Campaigns also have other elements, depending on the specific vulnerabilities of employers, including employee petitions, wearing signs to express union support, picketing, and media pressure to draw attention to aggressive employer conduct.

\section{Organizing Successes in Estonia}

The BOA in Estonia is regarded as having been fairly successful. The BOA's annual reports show that by November 2014, in the third year of operations, 1234 new members had joined, 48 new shop stewards were recruited and 15 new self-sustaining branches were set up in Estonia (BOA, 2014). The aggregate numbers may seem small, but it is important to remember the total population of Estonia is only 1.3 million, and the labour movement is starting from a very low baseline.

During this initial period, most successes were in manufacturing and transportation, while services saw less success. Partly, this was because the starting situation in that sector was so bad. Despite this, PAM continued to underwrite ETKA's campaigns, because of what they saw as positive signs at targeted firms. Officials from PAM also emphasized that 2012 to 2014 was a learning period, during 
which the Estonian organizers' professionalism increased (PAM official, November 2014). Preliminary numbers from 2016 now suggest that this patience paid of; ETKA, which had two organizers, organized 160 new members in that period (Mölder, 2016).

The best example of BOA strategy's success is actually its spillover effect - or frame diffusion (Benford and Snow, 2000: 627) - and comes from EMSA, outside the formal BOA program (although EMSA has since joined BOA). A former Estonian BOA country coordinator started working for EMSA - a union with close links to the Finnish Seamen's Union - with the task of unionizing the Tallink Group hotels. Tallink is an Estonian ferry company. Using BOA tactics, he successfully organized the hotel staff and recruited a chief shop steward. EMSA won a collective agreement including a wage increase and other benefits (former Estonian BOA country coordinator December 2014). When Tallink fired a newly elected shop steward in spring 2014, EMSA mobilized support: BOA's Estonian activists organized a picket, and requested solidarity from Finnish unions. The Central Organisation of Finnish Trade Unions SAK threatened to end its service contracts with Tallink's hotels and the Finnish Seamen's Union threatened a secondary strike on its vessels. Tallink reinstated the shop steward.

Participation in the BOA has also shifted the mentality of unionist not directly involved in organizing as such, as this quote from an ETKA official illustrates:

/.../ in previous years... communication with workers was a bit superficial meaning that, well, let's say a person came and wanted to join the union, we were really glad that he/she joined and we did talk a bit about unions, but we did not have so-called long and comprehensive conversations with workers. Moreover workers should realize that they are the union. (ETKA official, September 2014) 
Organizing also gained ground within Estonian trade unions outside the BOA. The main Estonian trade union confederation EAKL incorporated organizing elements into their general shop stewards' training module. These were introduced in the trainings by BOA organizers (EAKL official \#2, December 2014).

There were detractors as well. Organizers report some officials continue to not support organizing, although in some cases this has lessened with organizing successes:

/.../ in the beginning older coordinators were quite sceptical towards it [organizing]. Like what do you mean?... we have done things here certain way for decades and now some young guy comes and tells you have done everything the wrong way. /.../ now... it seems they are starting to understand why and how it works so that they have started even to use certain methods in their work. But I have not been able to change them 100\%. Those younger ones who joined later, they have come along with this thing [the organizing approach]. Older unionists are watching... how it goes for me and then well, they see that there are results and this probably increases their belief /.../ (BOA organizer \#3, May 2015)

Still, part of the opposition was not related to effectiveness, but rather approach and ideology. For example, two Estonian manufacturing unions quit the Academy at the end of 2014. One reason they gave was discomfort with the confrontational approach, including keeping organizing secret from employers (AEEWTU official, March 2015).

\section{The Spread to Finland}


The BOA has been a mutual learning process for the Finnish and Estonian unions, influencing the strategies of Finnish unions as well. Finnish and Estonian industrial relations contexts and organizing challenges are different. While Estonian workplaces are usually poorly organized, in Finland poorly organized workplaces are rare. Nonetheless, Finnish unions have been concerned about a lack of member engagement (i.e. the need for internal organizing), and many family firms and entrepreneurs remain staunchly non-union (Laurokari, 2016). Arnholtz et al. (2016) describe the Danish case, which is in many ways similar to the Finnish one. In that context, rank and file mobilization to establish union representation in previously unorganized workplaces has been virtually unknown in recent decades. The main issues which inspire mobilization in low-density contexts are usually already addressed in Denmark. Contracts are agreed at the industry level and workers have access to union representation if they want it. While unions see worker mobilization as necessary to build power resources to maintain and improve conditions, guaranteed representation promotes a passive mentality in the workers (Arnholtz et al., 2016).

Finnish unions also benefit from high-density passive recruitment environment, where members come to the union for unemployment benefits and representation services, rather than the union coming to them. This promotes membership, but discourages engagement. As with the Danish organizing advocates (Arnholtz et al., 2016), Finnish organizing model advocates point out that organizing is not alien to Finland, but rather invokes methods and ideologies of the labour movement's formative years (Pietarinen, 2014), drawing on this older tradition to legitimate organizing. One of the BOA initiators, Mika Häkkinen (2016: 12) stated in the metalworkers' union newsletter: 'It is not a question of something new. For example, Finnish unions before the Second World War had organizers whose job was to found new union structures'. 
Metalliliitto was the first to adopt organizing model tactics. Their local officials were at first hesitant, but opinions became more positive when the results of the Estonian campaigns emerged (Metalliliitto official \#3, March 2015). During the first year in the Metalliliitto's campaign, the number of shop stewards increased by 100 and the number of new members in targeted firms was 200 (Pietarinen, 2014). Although the outcome has been modest in terms of increased membership levels (i.e. external organizing), internal organizing has had promising results. The BOA-inspired campaign has made union people change their attitudes towards recruitment (Metalliliitto official \#3, March 2015). In 2016 PAM also trained its staff in basic organizing model principles and around 20 people who use organizing in their also work received advanced training. They are widening the scope of organizer training and organizing activities in 2017 (PAM official, December 2016).

\section{Conclusions}

This article seeks to explain how Finnish and Estonian union overcame the double barrier to transnational organizing cooperation through identity work. We conclude that the underlying need to increase union leverage provided motivation to try the organizing model, but it could only be successfully implemented through an extended process of identity work, in which old ideas about national jurisdictions and social partnership were contested by new ideas of international cooperation and aggressive campaigning. Finnish unions' motives first and foremost related to the competitive threat posed by competition from non-union Estonians. For Estonian unions, the BOA was a reaction to declining membership. Despite the bargaining logic, the change of strategy was neither automatic nor inevitable, but required extensive identity work on both sides of the Gulf of Finland.

Furthermore, the organizing model ideas were tested in action, as successful identity work presumes simultaneous processes of framing and engagement in collective action (Snow and McAdam, 2000). 
Personal contacts and long-established cooperation played a central role in beginning and sustaining the BOA. The Finnish unions gave the Estonian unions resources, but also took a step back and let the Estonians run the campaigns, so that it was a mutual learning process, rather than being dominated by the stronger union movement. The Estonian unions had to justify the trust put in them by assuming the organizing model agenda. This trust and commitment was only possible because of the years of identity work preceding the BOA. The Scandinavians lack such strong bond with Latvia and Lithuania, explaining why the Academy has not enjoyed similar success there.

The need for a new, dynamic strategy was advocated by a few 'old-school' Finnish and Estonian trade unionists who had studied the model elsewhere in Europe, and believed it could work in Baltic and Nordic countries as well. This underlines the importance of agents in promoting ideas of change (Hauptmeier and Heery, 2014), the need for constant identity work to create common understandings and objectives (Greer and Hauptmeier, 2012) and the socialization of old and new union members into accepting these. As the approach is considerably different from how unionists' have seen their and their organizations' role this far, it takes skilful framing (e.g. referring to organizing as return to the origins for Finnish unions, or as an only way to save Estonian unions) by the main advocates of the approach to legitimize the more confrontational strategy and ensure its continuity.

Identity work is a contested process and some changes are easier to achieve than others, depending on their fit with the past frames and narratives of the decision makers whose views are to be changed. Older generation partnership-servicing oriented unionists might see the need to organize, but confronting and pressuring employers is another and more difficult step. This generates tensions between those favouring more aggressive organizing and those who cling to existing union identities. The latter group opposes aggressive tactics, even when these clearly bring gains for workers. The BOA resolved this by being organizationally separate from other parts of the union movement, 
allowing freedom of action and limiting opposition, at the cost of making the number of 'identity work subjects' smaller. If the model is to become general it is necessary to reconnect it to the rest of the union movement. This is probably the BOA's most crucial future challenge. 


\section{References}

Arnholtz J, Ibsen CL, and Ibsen F (2016) Importing low-density ideas to high-density revitalisation: The 'organising model' in Denmark. Economic and Industrial Democracy 37(2): 297-317.

Benford RD, Snow DA (2000) Framing processes and social movements: An overview and assessment. Annual review of sociology 26(1): 611-639.

BOA (2014) BOA 2015. Presentation by Nordic BOA coordinator for Estonia, Teollisuuden Palkansaajat (TP), 1 December 2014.

Bronfenbrenner K (1997) The Role of Union Strategies in NLRB Certification Elections. Industrial and Labor Relations Review 50(2): 195-212.

Böckerman P, Uusitalo R (2006) Erosion of the Ghent System and Union Membership Decline: Lessons from Finland. British Journal of Industrial Relations 44(2): 283-303.

Connolly H, Marino S, and Martinez Lucio M (2017) 'Justice for Janitors' goes Dutch: the limits and possibilities of unions' adoption of organizing in a context of regulated social partnership. Work, employment and society 31(2): 319-335.

Cooke W (2005) Exercising Power in a Prisoner's Dilemma: Transnational Collective Bargaining in an Era of Corporate Globalisation? Industrial Relations Journal 36(4): 283-302. 
De Turberville S (2004) Does the Organising Model represent a Credible Union Renewal Strategy? Work Employment and Society 18(4): 775-794.

De Turberville S (2007) Union organizing: a response to Carter. Work, Employment and Society 21(3): 565-576.

Durrenberger P (2009) If you have a strong union, you don't need a necktie: U.S. labor and global solidarity. Dialectical Anthropology 33(2): 129-141.

Fiorito J (2004) Union Renewal and the Organizing Model in the United Kingdom. Labor Studies Journal 29(2): 21-53.

Fletcher B, Hurd R (2001) Overcoming obstacles to transformation. In Turner L, Katz H, and Flectcher, B (eds) Rekindling the Movement: Labor's Quest for Relevance in the $21^{\text {st }}$ Century. Ithaca: Cornell University Press, 182-210.

Greer I, Hauptmeier M (2012) Identity work: Sustaining transnational collective action at General Motors Europe. Industrial Relations: A Journal of Economy and Society 51(2): 275-299.

Gumbrell-McCormick, R and Hyman, R. (2015) Trade Unions in Western Europe: Hard Times, Hard Choices, Oxford: Oxford University Press.

Hauptmeier M, Heery E (2014) Ideas at work. The International Journal of Human Resource Management 25(18): 2473-2488. 
Heery E, Simms M, Delbridge R, Salmon J, and Simpson D (2000) Union organizing in Britain: a survey of policy and practice. International Journal of Human Resource Management 11(5): 9861007.

Häkkinen M (2013) The Baltic Organizing Academy. How to Build a Multinational and Multisectoral Organizing Program. Fridrich Ebert Stiftung.

Häkkinen M (2016) BOA järjestää Baltiaa. Ahjo 21 January 2016.

Kelly J (2004) Social Partnership Agreements in Britain: Labor Cooperation and Compliance. Industrial Relations: A Journal of Economy and Society 43(1): 267-292.

Kettunen P (2004) The Nordic model and consensual competitiveness in Finland. In: Castren A-M, Lonkila M, and Peltonen M (eds) Between Sociology and History. Essays on Microhistory, Collective Action, and Nation-Building. Helsinki: SKS (Finnish Literature Society), 289-309.

Kettunen P (2012) Reinterpreting the Historicity of the Nordic Model. Nordic Journal of Working Life Studies 2(4): 21-43.

Krzywdzinski M (2010) Organizing employees in Central Eastern Europe: The approach of Solidarność. European Journal of Industrial Relations 16(3): 277-292.

Laurokari A (2016) Suomen Yrittäjät vastustaa paikallisen sopimisen kompromissiesitystä. Ilkka 1 June 2016. 
Milkman R (2006) L.A. Story: Immigrant Workers and the Future of the US Labour Movement. NY:

Russell Sage Foundation.

Mölder V (2016) BOA Facilitator Group Meeting. 12 December 2016.

PAM (2009) PAMin maahanmuuttajajäsenet vuosina 2002 ja 2008. Available at:

https://www.pam.fi/media/1.-materiaalipankki-tiedostot-nakyvat-julkisessa-

materiaalipankissa/tilastot-ja-tutkimukset/maahanmuuttajatutkimusten-yhteenveto-1.3.2009.pdf

Pietarinen A (2014) Pakko tehdä jotain. Palkkatyöläinen (SAK newspaper) 15 April 2014. Available at: https://www.sak.fi/luottamushenkiloille/jutut/pakko-tehda-jotain-2014-04-15

Schymik C (2013) The Baltic Sea Region: Who Co-operates with Whom and Why? In: Billini N, Hilpert U (eds) Europe's Changing Geography: the Impact of intra-Regional Networks. Routledge, $67-80$

Schwalbe ML, Mason-Schrock D (1996) Identity work as group process. Advances in group processes 13: 113-147.

Simms M (2012) Imagined solidarities: Where is class in union organising? Capital \& Class 36(1) $97-115$.

Simms M, Holgate J (2010) Organising for what? Where is the debate on the politics of organising? Work, Employment and Society 24(1): 157-168. 
Skulason A, Jääskelainen M (2000) Regional co-operation within the Nordic Council of Trade Unions and across the Baltic Sea. Transfer: European Review of Labour and Research 6(1): 78-91.

Snow D A, Anderson L (1987) Identity work among the homeless: The verbal construction and avowal of personal identities. American journal of Sociology 92(6): 1336-1371.

Snow D, McAdam D (2000) Identity Work Processes in the Context of Social Movements: Clarifying the Identity/Movement Nexus. In: Stryker S, Owens TJ, and White RW (eds) Self, Identity and Social Movements. Minneapolis: University of Minneapolis Press, 41-67.

Turner L (1998) Fighting for Partnership: Labor and Politics in Unified Germany. Ithaca: Cornell University Press.

Turner L (2009) Institutions and Activism: Crisis and Opportunity for a German Labor Movement in Decline. Industrial and Labor Relations Review 62(3): 294-312.

Visser J (2015) ICTWSS Data base version 5.0. Amsterdam: Amsterdam Institute for Advanced Labour Studies AIAS. Available at: www.uva-aias.net/208

Voss K, Sherman R (2000) Breaking the iron law of oligarchy: Union revitalization in the American labor movement. American Journal of Sociology 106(2): 303-349.

Woolfson C, Kallaste E (2011) 'Illusory Corporatism "Mark 2"' in the Baltic States. Warsaw Forum of Economic Sociology 2(3): 51-72. 